\title{
Malaria among Croatian seafarers between 2004 and 2014: evaluation of chemoprophylaxis use and occupational disease reporting
}

\author{
Fani Žunić-Pedisić ${ }^{1}$ and Bojana Knežević ${ }^{2}$ \\ ${ }^{1}$ Institution for Health Care, Occupational and Sports Medicine dr. Fani Žunić Pedisić, Zadar, Croatia \\ ${ }^{2}$ University Hospital Centre Zagreb, Zagreb, Croatia
}

[Received in October 2021; Similarity Check in October 2021; Accepted in December 2021]

\begin{abstract}
In Croatia, malaria was eradicated in 1964 and has since been imported, ten cases a year in average, mostly by Croatian migrant workers, seafarers in particular. About $80 \%$ of registered cases were infected in Africa and the main reason for infection was negligence in the use of chemoprophylaxis. The aim of the study was to establish the incidence of malaria among Croatian seafarers from 2004 to 2014, how many of them took chemoprophylaxis properly, and whether malaria was acknowledged as occupational disease. To get our answers we analysed epidemiological surveys of the Croatian Institute of Public Health completed by patients and reviewed epidemiological bulletins and the national Register of Occupational Diseases. Over the investigated period, a total of 102 people fell ill with malaria, of whom 25 were seafarers. Seventeen did not take chemoprophylaxis at all and eight took them without following instructions. In addition, none of them had malaria recognised as occupational disease under Croatian law, nor is there any information that they exercised their rights in any other way. All this clearly points out that seafarers and their employers need to be informed much better about the benefits of preventive measures and their labour rights.
\end{abstract}

KEY WORDS: education; epidemiology; prophylaxis

Malaria is a life-threatening tropical infectious disease caused by parasites of the genus Plasmodium entered into humans by the bite of female Anopheles mosquitoes (1). Almost half of the world's population is at risk of contracting malaria. The World Health Organization (WHO) estimates that the number of clinical malaria cases worldwide was 229 million in 2019 (2). The highest number of cases and deaths was recorded in Africa. Malaria killed 409,000 people in 2019, mostly children aged under 5 years $(67 \%)(2)$.

Malaria is prevented by chemoprophylaxis, vaccination, bite-avoidance, and vector control. Currently, no malaria vaccine is commercially available for travellers, and repellents are considered the most important measure to prevent infection. In high-risk destinations chemoprophylaxis is strongly advised (3-4). Even though vector control (draining wetlands and use of insecticides to destroy mosquitoes) has successfully eradicated the disease in many countries, it remains a major problem in poor subtropical and tropical areas $(2,5-7)$.

In Croatia, malaria was officially eradicated in 1964 (8-10), but no autochthonous infections have been recorded since 1958 (9). A retrospective study of the incidence of

Corresponding author: Fani Žunić Pedisić, Institution for Health Care, Occupational and Sports Medicine, Novogradiška 2, Zadar, Croatia e-mail: fanipedisic@gmail.com malaria in Croatia (8) between 1987 and 2006 reported 201 cases, mostly in seamen (70\%), workers in tropical countries, and tourists.

Croatia has about 30,000 seafarers, $70 \%$ of whom sail under foreign flags (9). Traveling to different parts of the world and the characteristic way of life on board exposes them to infections to which they would rarely be exposed in their countries of origin. According to the 2006 Maritime Labour Convention and Croatian regulations (11-13), every seafarer must have a valid medical certificate to perform duties at sea. Malaria infection in seafarers is a major public health problem (14-16), with the incidence from 500 to 1,000 a year worldwide (14), and prevention should be based on antimalarial prophylaxis taking into account its benefits and risks, including side effects and the actual risk of developing infection in tropical ports.

The aim of our retrospective cohort study was to investigate the incidence of malaria in Croatia from 2004 to 2014, determine the share of infected seafarers, and establish how many of them took chemoprophylaxis. Considering that an infectious disease contracted at work is considered occupational (17), our secondary aim was to see whether seafarers with malaria exercised their right to claim occupational disease with their employer and/or health insurance. 


\section{METHODS}

Our analysis relied on data collected from epidemiological journals registering malaria cases in Croatia and questionnaires completed by malaria patients from 2004 to 2014, which are available in the archive of the Croatian Institute of Public Health (CIPH) epidemiology service. The questionnaires contain personal and other demographic information (gender, age, education, occupation) and information about how the patient contracted malaria, in which country, how severe the symptoms were, whether they used prophylaxis (specific drug, according to which scheme, how regularly, and for how long), and whether they received antimalarial treatment upon return home. We then compared the obtained data with those from the CIPH Register of Infectious Diseases and the Register of Occupational Diseases. The use of these data was approved by the ethics committees of CIPH and the University of Zagreb School of Medicine.

The data were analysed using descriptive statistics and the chi-squared test for differences in the use of chemoprophylaxis between seafarers and other malaria patients.

\section{RESULTS}

Between 2004 and 2014, a total of 102 cases of malaria were recorded ( 89 men, 8 women, and 5 undetermined), of which 25 among seafarers (24.5\%, all men). Other patients were skilled workers, university degree workers, and military staff of various professions. For 12 people there were no data on education or occupation (Table 1).

The highest incidence was recorded in 2012 and 2013, whereas no incidence among seafarers was recorded in 2008 and 2009 (Figure 1).

Table 2 shows the distribution of infected seafarers by endemic areas. Most were infected with Plasmodium falciparum $(\mathrm{N}=13$; Table 3$)$ and 21 were hospitalised, while four did not provide this information. Twelve were hospitalised in Croatia, two in Africa, one in Ukraine, and six did not provide this information. One sailor received outpatient treatment in Africa.

Table 1 Distribution of malaria patients by education and occupation between 2004 and 2014

\begin{tabular}{lcc}
\hline $\begin{array}{l}\text { Professional qualifications/ } \\
\text { occupation }\end{array}$ & $\mathbf{N}$ & $\mathbf{\%}$ \\
\hline Skilled worker & 31 & 30.39 \\
\hline University degree workers & 25 & 24.51 \\
\hline Seafarers & $\mathbf{2 5}$ & $\mathbf{2 4 . 5 1}$ \\
\hline Active military personnel & 6 & 5.88 \\
\hline Unemployed & 3 & 2.94 \\
\hline Unknown & 12 & 11.76 \\
\hline Total & 102 & 100.00 \\
\hline
\end{tabular}

Table 2 Distribution of seafarers with malaria by areas of infection

\begin{tabular}{lc}
\hline Endemic area & Number of infected seafarers \\
\hline Ivory Coast & 5 \\
\hline Nigeria & 4 \\
\hline Mozambique & 1 \\
\hline Cameroon & 2 \\
\hline Congo & 1 \\
\hline Equatorial Guinea & 2 \\
\hline Angola & 3 \\
\hline Gana & 2 \\
\hline Sierra Leone & 3 \\
\hline Zambia, Burkina Faso & 1 \\
\hline Unknown & 1 \\
\hline
\end{tabular}

Of the 25 seafarers, one 33-year-old died. He had stayed in Nigeria for six months before infection.

Of the total of 102 patients, only 24 took chemoprophylaxis ( 8 of 25 seafarers and 16 of 79 others), while 69 reported taking none at all (17 of 25 seafarers and 52 of 79 others), and nine did not provide this information. Upon return, only 9 of the 24 patients who took chemoprophylaxis continued taking prophylaxis. Three were taking mefloquine tablets for two, four, or six weeks. Two were taking atovaquone/proguanil tablets, one for three and the other for 28 days. Two were taking $100 \mathrm{mg}$ doxycycline tablets, one for several days, the other for 1 month, while one person continued with the unknown medication for only two days. No difference in the frequency of prophylaxis was observed between seafarers and others (chi-squared $=3.933 ; \mathrm{df}=2 ; \mathrm{P}=0.14$ ).

Prophylaxis taken by eight seafarers before and during the voyage included mefloquine, atovaquone/proguanil, and doxycycline tablets. However, all admitted not to have strictly followed instructions for use.

Upon return, only three seafarers continued taking their medication but not long enough, according to guidelines (18). All reported to the national epidemiology register and were instructed to follow antimalarial measures. Of 25 sick seafarers, 24 answered in the questionnaire that they did not take any antimalarial measures, such as household inspection and spraying with insecticide and medical examination. Only one seafarer reported spraying the household with insecticide and took medical examination.

Table 3 Distribution of seafarers and other malaria patients by infectious organism

\begin{tabular}{lcc} 
Type of Plasmodium & $\begin{array}{c}\text { Seafarers } \\
\text { N }\end{array}$ & $\begin{array}{c}\text { Others } \\
\text { N }\end{array}$ \\
\hline Unknown & 10 & 38 \\
\hline$P$. ovale or P. vivax & 1 & 2 \\
\hline$P$. falciparum & 13 & 39 \\
\hline$P$. falciparum and $P$. ovale & 1 & 1 \\
\hline$P$. falciparum and $P$. vivax & 0 & 1 \\
\hline
\end{tabular}




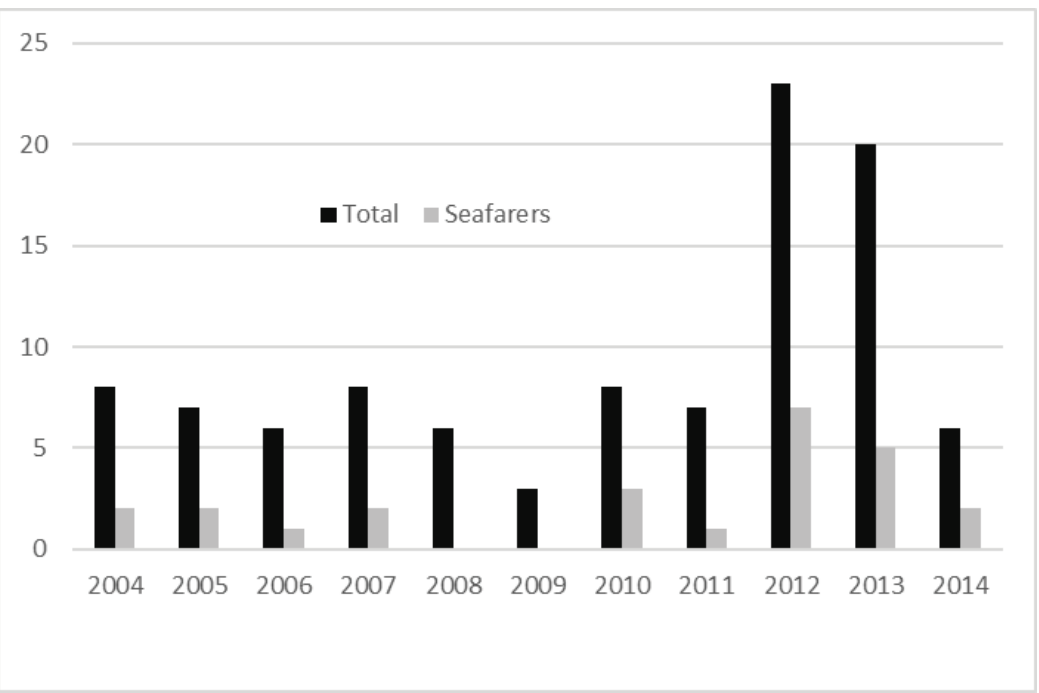

Figure 1 Incidence of malaria cases imported in Croatia between 2004 and 2014

As for our secondary aim, none of the sick seafarers exercised their right to claim occupational disease. Only one malaria case was claimed and recognised as occupational in 2014, but not by a seafarer.

\section{DISCUSSION}

The results of this ten-year retrospective cohort study has showed a large drop in malaria incidence among seafarers and a drop in prevalence compared to all recorded patients with respect to earlier reports (8-10). As expected, most were infected in Africa by P. falciparum, which is in line with other reports $(2,8,9,16,19-22)$. It has also showed some weaknesses in the system of recording, prevention, and follow-up of malaria cases in the country. Some countries have a better recording system, most notably great seafaring nations with frequent cases of imported malaria, such as Spain, France, United Kingdom, Germany, and Italy. Poland and Lithuania have a similar problem with reporting as Croatia, because many seafarers sail under foreign flags and are treated for malaria in the ports of call, which is not recorded in national databases (19-20).

What raises the greatest concern, however, is that almost two-thirds of all patients (seafarers included) do not observe chemoprophylaxis at all. Only eight seafarers in our study took chemoprophylaxis before and during their stay in endemic areas, and only three continued to take it upon return. Furthermore, none was taking it in accordance with standards of care, which shows a decline from the earlier twenty-year report (8). Studies from other countries confirm poor compliance of seafarers with instructions for use of antimalarial drugs (19-22). One Polish study (20) concluded that even though information about correct use of prophylaxis was publicly available on the Internet, as was pre-travel medical counselling, people traveling to tropical countries were still poorly informed, which increases the risk of them contracting malaria.

According to the Croatian Act on the list of occupational diseases, malaria contracted during work is considered an occupational disease (17), yet it has not been reported in the Croatian Register of Occupational Diseases as such for any seafarer between 2004 and 2014 (23).

Our study is limited to data provided by the Croatian Institute of Public Health, which are incomplete and separated from occupational disease reporting, as we cannot claim with certainty that none of the seafarers exercised their right to claim occupational disease with foreign insurers, but we can reasonably establish that no such information has been recorded in Croatia. And this is perhaps the central conclusion of our study: there is no system which constantly monitors seafarers and their health and links national and international disease databases. In addition, further research should include occupational health and labour law issues.

In the meantime, education about safety at work and prevention measures needs to be improved, such as through continuing education on tropical infectious diseases and their symptoms and through clearly instructing all migrant workers how to take prophylaxis. A multidisciplinary approach to the issue is important, and it should involve cooperation between occupational medicine specialists, employer representatives, epidemiologists, and seafarers.

Table 4 Distribution of seafarers and other malaria patients by whether they took prophylaxis

\begin{tabular}{lcc}
$\begin{array}{l}\text { Has chemoprophylaxis been } \\
\text { taken before this disease? }\end{array}$ & $\begin{array}{c}\text { Seafarers } \\
\text { N }\end{array}$ & $\begin{array}{c}\text { Others } \\
\text { N }\end{array}$ \\
\hline No data & 0 & 9 \\
\hline Yes & 8 & 16 \\
\hline No & 17 & 52 \\
\hline
\end{tabular}




\section{REFERENCES}

1. Kuzman I, Schönwald S. Infektologija [Infectology, in Croatian]. Zagreb: Medicinska naklada; 2000.

2. World Health Organization (WHO). World Malaria Report. Geneva: WHO; 2020.

3. Aschley EA, Phyo AP, Woodrow CJ. Malaria. Lancet 2018;391:1608-21. doi: 10.1016/S0140-6736(18)30324-6

4. Kuna A, Gajewski M. Malaria vaccine for travellers - where are we now? Int Marit Health 2019;70:65-7. doi: 10.5603/ IMH.2019.0010

5. Talapko J, Škrlec I, Alebić M, Jukić M, Včev A. Malaria: the past and the present. Microorganisms 2019;7(6):179. doi: 10.3390/microorganisms7060179

6. Nikolic N, Poljak I, Troselj-Vukic B. Malaria, a travel health problem in the maritime community. J Travel Med 2000;7:309-13. doi: 10.2310/7060.2000.00084

7. Ropac D, Puntarić D, editors. Epidemiologija zaraznih bolesti [Epidemiology of the infectious diseases, in Croatian]. Zagreb: Medicinska naklada; 2010.

8. Perić D, Škrobonja I, Škrobonja A. Malarija u Hrvatskoj u razdoblju od 1987. do 2006. [Malaria in Croatia in period between 1987 to 2006, in Croatian]. Liječ Vjesn 2009;131:192-5.

9. Mulić R, Aljinović L, Gizdić Z, Petri NM. Malarija u Hrvatskoj: nekad, danas i sutra [Malaria in Croatia: in the past, today and tomorrow, in Croatian]. Liječ Vjesn 2000;122:51-5.

10. Mulić R. Malaria in Croatia: from eradication until today. Malaria J 2012;11(Suppl 1):P135. doi:10.1186/1475-287511-S1-P135

11. Pomorski glasnik - Konvencija o radu pomoraca 2006. $/$ Nautical Courier - Marine Workers Convention 2006 [displayed 7 December 2021]. Available at https://sph.hr/ upload/2012/10/konvencija_o_radu_pomoracahrv_i eng_2_507e761e3e18e

12. International Labour Office (ILO). Guidelines on the medical examinations of seafarers, 2013 [displayed 7 December 2021]. Available at https://www.ilo.org/wcmsp5/groups/ public/---ed_dialogue/---sector/documents/ normativeinstrument/wcms 174794.pdf

13. Pravilnik o izmjenama i dopunama pravilnika o utvrđivanju uvjeta zdravstvene sposobnosti članova posade pomorskih brodova, brodica i jahti [Ordinance on amendments to the ordinance on determining the conditions of medical fitness of crew members of seagoing ships, boats and yachts, in Croatian]. Narodne novine 107/2014.

14. Tomaszunas S. Malaria in seafarers. 1. The magnitude of the problem and the strategy of its control. Bull Inst Marit Trop Med Gdynia 1998;49:53-61. PMID: 10431646

15. Wernsdorfer WH. Protection against malaria among seafarers. Int Marit Health 2002;53:7-17. PMID: 12608584

16. Tomaszunas S. Malaria in seafarers. 2. The status of malaria in large ports of the world. Protective measures against malaria in crews of ships. Bull Inst Marit Trop Med Gdynia 1998;49:63-71. PMID: 10431647

17. Zakon o listi profesionalnih bolesti [Law on the List of Occupational Diseases, in Croatian]. Narodne novine 162/1998, 107/2007.

18. Centers for Disease Control and Prevention (CDC). Choosing a drug to prevent malaria [displayed 9 December 2021]. Available at https://www.cdc.gov/malaria/travelers/drugs. html

19. Scerbaviciene R, Pilipavicius R. Malaria among seafarers in Klaipeda in 1999-2008. Int Marit Health 2009;60:29-32. PMID: 20205124

20. Kuna A, Gajewski M, Stanczak J. Evaluation of knowledge and use of the malaria prevention measures among the patients of the Department of Tropical and Parasitic Diseases University Center of Maritime and Tropical Medicine, Gdynia, based on a questionnaire performed in the years 2012-20. Przegl Epidemiol 2017;71:33-44. PMID: 28654740

21. Jaremin B, Nahorski W, Goljan J, Felczak-Korzybska I, Gorski J, Myjak P, Kotlowski A. Malaria as an occupational disease. Bull Inst Marit Trop Med Gdynia 1993-1994;4445:43-50. PMID: 7580349

22. Shoda M, Shimizu K, Nagano M, Ishii M. Malaria infections in crews of Japanese ships. Int Marit Health 2001;52:9-18. PMID: 11817846

23. Hrvatski zavod za zaštitu zdravlja i sigurnost na radu. Registar profesionalnih bolesti [Register of occupational diseases, in Croatian] [displayed 25 May 2018]. Available at http://www.hzzzsr.hr/wp-content/uploads/2016/11/reg prof_2017_1.pdf

\section{Malarija među hrvatskim pomorcima u razdoblju 2004.-2014.: evaluacija primjene kemoprofilakse i prijave profesionalne bolesti}

U Hrvatskoj je malarija iskorijenjena 1964. godine, a u sljedećim godinama importirano je oko deset slučajeva godišnje, najčešće se radilo o hrvatskim radnicima migrantima, posebice pomorcima. Oko 80 \% registriranih slučajeva zarazilo se u Africi zbog nepravilne primjene kemoprofilakse. Cilj ovoga istraživanja bio je utvrditi incidenciju malarije hrvatskih pomoraca od 2004. do 2014. godine, istražiti jesu li pravilno uzimali kemoprofilaksu te je li im malarija priznata kao profesionalna bolest. Da bismo odgovorili na ta pitanja, analizirali smo epidemiološku anketu Hrvatskoga zavoda za javno zdravstvo, koju su ispunili pacijenti, te smo pregledali epidemiološka izvješća i nacionalni Registar profesionalnih bolesti. U promatranom razdoblju ukupno su 102 osobe oboljele od malarije, od kojih je 25 pomoraca. Sedamnaest pomoraca nije uzimalo kemoprofilaksu uopće, a osam ih je uzimalo, ali ne prema uputama. Također, nikomu od njih malarija nije priznata kao profesionalna bolest prema hrvatskom zakonodavstvu niti ima informacija jesu li svoja prava ostvarili na bilo koji drugi način. Sve to jasno upućuje na zaključak da pomorci i njihovi poslodavci trebaju biti bolje informirani o dobrobitima preventivnih mjera i o svojim radnim pravima. 